\title{
First report of cytogenetic studies in Spanish breed horses
}

\author{
M Moreno-Millán, A Rodero, FJ Alonso, A Sanz \\ Instituto de Zootecnia, CSIC, Facultad de Veterinaria, \\ Laboratorio de Citogenética, Unidad de Genética, 14005 - Córdoba, Spain
}

(Proceedings of the 9th European Colloquium on Cytogenetics of Domestic Animals; Toulouse-Auzeville, 10-13 July 1990)

chromosomes / horse / abnormalities

During the past three years, our laboratory has been cytogenetically studying Spanish breed horses in general and, more particularly, those animals which had some type of irregularity in their reproductive capacity. We found two types of chromosome alterations related to these irregularities.

Sixty Spanish breed horses of both sexes, including 10 females with reproductive problems and 5 subfertile males, were studied. Three of these females had the appearance of intersex horses with marked stallion behavior and with no apparent estrus. The remaining 7 were phenotypically normal females with highly irregular estrus cycles and a history of miscarriages. The 5 subfertile males studied had very poor quality semen, with little motility or azoospermy. They were phenotypically normal.

Peripheral blood cultures were set up using a slightly modified version of de Grouchy et al's (1964) method. Twenty-four hours after treatment, the G- and C-banding techniques were applied to the preparations obtained by air-drying, according to the methods of Dutrillaux and Lejeune (1971) and Sumner (1972), respectively.

The G-banded karyotypes were sorted following the recommendations of the Reading Conference (1976) (Ford et al, 1980), while the sex chromosomes were identified according to Blue et al (1978).

The analyses gave the following results.

For a phenotypically intersex mare with the characteristics of a pseudohermaphrodite male: the vulva was normal but 2 testicular formations were found in the inguinal region and a short vagina closed at the end; no uterus or ovaries were detected; cytogenetic analysis showed the presence of an X-trisomy (Moreno Millán et al, 1989).

For 2 mares whose external examinations showed one of them to be a normal female with a perineal area and vulva typical of a nulliparous animal, rectal palpation revealed the presence of ovaries which were smaller than usual and smooth 
surfaced. This animal showed aggressive behavior towards the males, had no estrus and did not respond to the conceptive treatment prescribed. Cytogenetic analysis revealed that the animal was a carrier of the cellular XX/XY chimerism.

We also had the opportunity to study a young mare with an external appearance of intersex. Instead of ovaries, we found only a structure on the left side, similar to a testicle, $4 \mathrm{~cm}$ long and $2 \mathrm{~cm}$ wide, with a smooth surface and thick walls. Histological analysis showed an absence of primordial follicles and severe ovarian hypoplasia. No structure was observed which might correspond to a testicle. The animal's the chromosome complement was XX/XY chimerism, with a predominance of the XX population.

In the literature consulted on $\mathrm{XX} / \mathrm{XY}$ chimerism in the horse, we found that this anomaly is associated with a vascular anastomosis between dizygotic fetuses which gives rise to fertile mares, the opposite of what happens in cattle (Bouters and Vandeplassche, 1972; Podliachouk et al, 1974). The few known cases of true hermaphrodites with XX/XY chromosome constitution (McIlwraith et al, 1976; Dunn et al, 1981) had organs of both sexes which was doubtless the result of double fertilization. Given the characteristics analyzed, we think that the animals we studied can be classified as having gonadal dysgenesis and, more specifically, ovarian hypoplasia in the second animal and not intersexuality. Chandley et al (1975) observed an X-trisomy in a case of ovarian hypoplasia; the case cited here is the first in which ovarian hypoplasia is associated with XX/XY cellular chimerism.

The remaining 7 mares investigated presented reproductive alterations with highly irregular estrus cycles, defects in conception and spontaneous abortions. External and internal examinations revealed a normal female phenotype with completely normal external and internal genitalia; cytogenetic analysis determined that they were XX mares.

We investigated 5 phenotypically normal stallions that had poor quality semen, with very little motility; 2 of them were azoospermic. Cytogenetic analysis showed that all these animals had a normal XY chromosome complement.

\section{REFERENCES}

Blue MG, Bruère AN, Dewes HF (1978) The significance of the XO syndrome in infertility of the mare. New Zealand Vet J 26, 137-141

Bouters R, Vandeplassche M (1972) Twin gestation in the mare: the incidence of placental vascular anastomosis and their influence on the reproductive, performance of heterosexual equine twins. J Reprod Fertil 29, 149

Chandley AC, Fletcher J, Rossdale PD, Peace CK, Ricketts SW, McEnery RJ, Thorne JP, Short RV, Allen WR (1975) Chromosome abnormalities as a cause of infertility in mares. $J$ Reprod Fertil 23 (suppl), 377-383

de Grouchy J, Roubin M, Passage E (1964) Microtechnique pour l'étude des chromosomes humains à partir d'une culture de leucocytes sanguins. Ann Génét 7, 45-46

Dunn HO, Smiley D, Ducan JR, McEntee K (1981) Two equine true hermaphrodites with $64, \mathrm{XX} / 64, \mathrm{XY}$ and $63, \mathrm{XO} / 64, \mathrm{XY}$ chimerism. Cornell Vet 71, 123-135

Dutrillaux B, Lejeune J (1971) Sur une nouvelle technique d'analyse du karyotype humain. CR Acad Sci Paris Sér D 272, 2638-2640 
Ford CE, Pollock DL, Gustavsson I (1980) Proceedings of the First International Conference for the Standardization of Banded Karyotypes of Domestic Animals, Reading 1976. Hereditas 92, 145-162

McIlwraith CW, Owen R, Basrur PK (1976) An equine cryptorchid with testicular and ovarian tissues. Equine Vet $J$ 8, 156-160

Moreno-Millán M, Delgado JV, Lopez G (1989) An intersex horse with X-chromosome trisomy. Vet Rec 124, 169-170

Podliachouk L, Vandeplassche M, Bouters R (1974) Gestation gemellaire, chimerisme et freemartinisme chez le cheval. Acta Zool Pahol 58, 13-28

Sumner AT (1972) A simple technique for demonstrating centromeric heterochromatin. Exp Cell Res 75, 304-306 